\title{
Laczó, Ferenc and Gabrijelčič, Luka Lisjak, eds. The Legacy of Division East and West After 1989. Budapest: Central European University Press. 2020. 337 pp.
}

\section{Reviewed by Susan Glanz, St. John’s University, NY, glanzs@stjohns.edu}

The term "short twentieth century," as used in Craig Moran's well-known article with this title, refers to the period of seventy-seven years between 1914 and 1991. It is unique as a historic period, in that the dates of its beginning and end are clearly defined. In 1989, political scientist Francis Fukuyama wrote that we may be witnessing "not just the end of the Cold War... [but also] the universalization of Western liberal democracy as the final form of human government" ("The End of History?" The National Interest 16 (1989), 3-18). It is thus understandable that the editors of the book reviewed here chose 1989 as the date for the invited contributors to focus on. The central issue under the microscope was: Did the East-West divide disappear with the lifting of the Iron Curtain or was it transformed into new fissures? The editors of the volume invited specialists on the topic to answer this question. The twenty-four contributions included in this book had been previously published on the Eurozine website, but some of them have been updated for this publication.

There is no doubt that 1989 will be remembered as a crucial year in European history because this was the year when the Berlin Wall fell. In Hungary, it was the year of the Round Table Talks, a series of formalized, orderly discussions held in Budapest and resulting in the creation of a multi-party constitutional democracy. In Poland, the trade union Solidarity won an overwhelming victory in a partly free elections held that year. In Romania, the Ceausescu regime was overthrown, Ceausescu and his wife were sentenced to death by a revolutionist military court and immediately executed on Christmas Day 1989. In Czechoslovakia, demonstrations in the fall of that year led to the Velvet Revolution, a non-violent transition of power in the country, which by the beginning of 1993 became divided into the two Republics. In Bulgaria multiparty elections were held in 1990. In the former Yugoslavia, Slobodan Milošević's Gazimestan-Square Speech in Kosovo, in mid-1989, in which he outlined the program of resurgent Serbian nationalism, led to the dissolution of the Yugoslav state in 1991. One of the contributions also reminds the reader that, outside Europe, 1989 was the year of the violent suppression of the Chinese Tiananmen-Square democracy movement. The thirtieth anniversary of all these changes and revolutions allowed the contributors to reflect on questions such as which of the original goals were achieved, how the mix of liberal democracy, free markets and Western-led globalization were viewed in the East-Central European countries, and how the dissatisfaction with either the original goals or their lackluster achievements-at least in the public opinion-in the intervening thirty years lead to populism and crawling, pervasive authoritarianism.

The first article in the volume, written by Dorothee Bohle and Béla Greskovits, highlights some of the questions posed by the editors, e.g., how were the expectations of "returning to

$((\mathrm{cc}) \mathbf{E Y}$

ULIS D-Sork 
Glanz, Susan. "Laczó, Ferenc and Gabrijelčič, Luka Lisjak, eds. The Legacy of Division East and West After 1989. Budapest: Central European University Press. 2020. 337 pp." Hungarian Cultural Studies. e-Journal of the American Hungarian Educators Association, Volume 14 (2021) DOI: 10.5195/ahea.2021.444

Europe" in the sense of building a capitalist economy, met in the countries of ECE. Immediately after 1989, the popular perception in and about these Central European countries was that with time the old fault-lines would fade. But in reality, when as of 2004 most of them joined the European Union, the old fault-lines have actually (if they had ever faded) re-opened and new ones emerged. The authors argue that the new fault-lines were caused by three misperceptions, namely: that a Western-led market-based economy would allow for rapid convergence, which did not or could not happen; that the mobility of capital and labor will be problem-free for both the new and old EU member states; and that the EU is a guarantor of liberal democracy. The two authors' prescription to reducing the reopened cracks is a better understanding of the historical traditions of each nation and those of the EU.

All the authors, except for Owen Hatherley, agree that the divide between East and West has not disappeared but rather remained as it was, although in various new forms. Hatherley, by contrast, argues that the East-West (which in his article refers solely or mainly to the United Kingdom) divide has disappeared, and that it is the mission of the politicians to show that at present there are more similarities than differences between the countries of ECE and the UK. Hatherley also claims that currently the real divide in Europe is that between its northern and southern parts and countries. Likewise pondering old and new divides, Julia Sonnevend's personal article poses the question of when, for someone who has grown up in ECE in the 1980s and presently lives in Western Europe, the Eastern European habits and fears will eventually disappear. Her answer is that the divide has been so internalized by former citizens of ECE that it will take them a generation to overcome it.

Except for two contributions, all the articles focus on the European Union and some of the first entrants in 2004, namely Poland, Hungary, Romania, Czechoslovakia, and Slovenia. Some of these articles address the consequences of the unification of East and West Germany. Richard Sawka's article is one of the two articles that look beyond the EU borders. Sawka's analysis focuses on the changing goals of Russian politics following the dissolution of the U.S.S.R. The author traces the path leading from Boris Yeltsin's accommodationist policies that, as he hoped, would promote the country's transformation into a liberal and market democracy as well as a part of the Western world; and up to Vladimir Putin's rule and view that Russia must be an independent sovereign power in the international system. The other article looking beyond the EU is that by James Wang, who compares the disappointments of the East Germans and the Chinese following 1989 and the solutions offered by their respective governments. The Chinese government policy of high saving, high investment, and high growth economy practically legitimatizes this country's authoritarian rule, while at the same time questioning the traditional economic philosophy of democracy as a pre-condition for economic growth. Together, the two articles of Sawka and Wang suggest that the elimination of the East-West divide was understood, on both sides, as the replacement of Eastern ethos and practices by Westerns ones, and that once the Western-style democracy proved unattainable in or for countries such as Russia and China, illiberalism became an acceptable default in both.

The three contributions, of Philipp Ther, Claus Leggewie and Karl Schlögel, all concentrate on the impact of 1989 on Germany. Ther analyzes the consequences of economic transformations in Germany following the re-unification of its formerly Eastern and Western parts. Leggewie traces the impact of merging the six East German states into the unified Germany, which was not seamless and caused a new wave of "debourgeoisement" in the former East-Germany, and which to this day continues to impede the development of civil society in this 
Glanz, Susan. "Laczó, Ferenc and Gabrijelčič, Luka Lisjak, eds. The Legacy of Division East and West After 1989. Budapest: Central European University Press. 2020. 337 pp." Hungarian Cultural Studies. e-Journal of the American Hungarian Educators Association, Volume 14 (2021) DOI: 10.5195/ahea.2021.444

part of the country. Schlögel analyzes how, as a consequence of the Cold War, Western perceptions and sensitivity resulted in a continuous misunderstanding of the East.

The two articles written by Diana Georgescu and Jannis Panagiotidis examine the attitude of the EU member nations to immigration. Up until the early 2000s, Western European nations did not feel threatened by their "inferior eastern aliens," and westward immigration was not a serious issue. This situation changed once the EU membership of countries of ECE allowed for free movement of their people and many of them moved to the West. Georgescu concludes that this increased westward movement of people resulted in heightened prejudice toward the immigrants on many EU countries and in outright xenophobia in the UK. Yet, Panagiotidis contends that eventually these immigrants will become integrated into the host nations, and that it will be resentment toward immigrants from outside Europe that will become the unifying sentiment of both Eastern and Western Europeans. Florian Bieber, looking at the case of Slovenia, is optimistic about the future. Though agreeing that there are many fissures between East and West, he argues that coalition-building and transnational solidarity are possible and will eventually reduce the divisions. Bieber's use of statistics is at least partly inaccurate. For example, he writes that "Every single country except Slovenia has moved closer to the EU's average GDP per capita" (77). But according to the EU Eurostat Site, since 2015 and on, Slovenia has moved closer to the EU average and is now on the same level as, for example, the Czech Republic (on which see: https://ec.europa.eu/eurostat/databrowser/view/tec00114/default/table?lang=en).

Both Robert Bier and Zsófia Lóránd examine the impact of 1989 from the point of view of gender issues, and both conclude that, in retrospect, 1989 did not bring about the change hoped for by leaders of feminist movements in both the East and the West. Bier argues that the leading roles in the once dissident movements in ECE were later taken by males and that there was "an unspoken consensus between [the] dissidents and [the] regime about the 'naturalness' of received gender roles" (176). Lóránd focuses on the feminist dissident traditions in Yugoslavia. While gender equality and the women's-empowerment mandate were and are stated goals of all EU nations, its political tool is gender mainstreaming, which is a "set of specific, strategic approaches as well as technical and institutional processes adopted to achieve that goal [of gender equality]" (on which, see the report of the United Nations Women Organization, at: https://www.unwomen.org/en/how-we-work/un-system-coordination/gender-mainstreaming). Feminists hoped that with EU membership and the required acceptance of the principle of acquis communautaire, their demands would be met. But they were to be disappointed, as it all ended up by undercutting many of their efforts at substantial points, and even by triggering an antifeminist backlash.

Studying the post-1989 situation in Hungary, Holly Case posits that the emergence of illiberalism is a political strategy that was and still is successfully employed by Prime Minister Viktor Orbán. Bogdan Iacob and his co-authors, James Mark and Tobias Rupprecht, explain the recent rejection of Western liberalism in countries of ECE by the low support that these countries receive for promoting democracy. To this, one may add the disappointed expectations of transplanting components from the economies of Singapore and China as a faster way of raising the standards of living in ECE. Marius Stan and Vladimir Tismaneanu have a slightly different explanation for the shift to the political right in these countries, and they argue that for these peoples it is a manifestation of political anger coupled with perceived corruption and disappointment about not gaining the benefits expected from joining the EU and NATO. Barbara J. Falk analyzes how the goals of East European dissent and revolutions impacted other regions 
of the world, including the 2011 Arab Spring in countries such as Egypt, Libya, Syria and Yemen, and the 2018 events in Armenia.

The volume's last two pieces are conversations. In the first of these, Ivan Krastev explains his concept of "imitation by invitation" and the dissatisfaction it has led to in the countries of ECE. In the second conversation, held between a father and son, Igor Pomerantsev and Peter Pomerantsev, the two discussants put under the microscope the troubled relationship between Russia and "everything west" in light of various theories, from political to literary to psychological ones. As is often the case, collective volumes of articles cannot cover every possible angle or country related to their topic, and this volume also ignores a large swath of countries. Including a discussion of other countries that entered the EU at the same time as the countries discussed here (Estonia, Latvia, Lithuania, Slovakia and Bulgaria) would have made this publication more complete.

The overthrow of communism was peaceful in the majority of Central and Eastern European countries. Most citizens of East Central Europe viewed membership in the European Community as a prized goal that will aid rapid improvement in their standards of living, seamless inclusion in the European Market, and a democratic political system. While some economic successes cannot be denied, transformation was slow and unequal. After the global financial crisis of 2008, economic liberalism became burdened with statism, paternalism and oligarchic rule; and the crony model of capitalism or elements of authoritarianism ("illiberal democracy") reappeared. Therefore, largely, the conclusion drawn by most of the contributors for The Legacy of Division is that new curtains have appeared, but these are made of much lighter materials than the old Iron Curtain. 